\title{
Clinicopathological observations on metastasis in man studied in patients treated with peritoneovenous shunts
}

\author{
D TARIN, J E PRICE, M G W KETTLEWELL, R G SOUTER, A C R VASS, B CROSSLEY
}

\begin{abstract}
Fourteen patients with inoperable cancer treated with peritoneovenous shunts for malignant ascites were studied post mortem. Clinical observations and findings at necropsy indicated that peritoneovenous shunting does not result in the establishment of clinically important haematogenous metastases and that metastases do not necessarily develop even when large numbers of viable tumour cells regularly enter the blood.

Peritoneovenous shunting provides a unique opportunity for collecting data on the spread of tumours in man.
\end{abstract}

\section{Introduction}

The recent introduction of peritoneovenous shunting for treating intractable malignant ascites in patients with inoperable cancer $^{1-7}$ has provided an opportunity for collecting data, unobtainable ethically by any other means, on the mechanisms underlying metastatic dissemination and growth in man.

Peritoneovenous shunting has been used in the management of intractable malignant ascites for some years, but there has been no formal pathological evaluation in a large series of patients either of the practical consequences of haematogenous dissemination of viable tumour cells or of the scientific information that might be gained as a byproduct of the technique. Some previously published reports mentioned that necropsies had been

John Radcliffe Hospital, Oxford OX3 9DU

D TARIN, DM, MRCPATH, Nuffield reader in pathology

J E PRICE, BSC, research assistant, Nuffield department of pathology

B CROSSLEY, BM, BCH, lecturer, Nuffield department of pathology

$M$ G W KETTLEWELL, MCHIR, FRCS, consultant surgeon

R G SOUTER, MA, FRCS, lecturer, Nuffield department of surgery

Department of Obstetrics and Gynaecology, Wycombe General Hospital, High Wycombe, Buckinghamshire HP11 2TT

A C R VASS, FRCOG, consultant surgeon

Correspondence to: Dr D Tarin, Nuffield Department of Pathology, John Radcliffe Hospital, Oxford OX3 9DU. performed on some patients but did not provide details of the results. ${ }^{2-7}$ Two case reports, however, gave good pathological descriptions. $^{8}{ }^{9}$

Over three years 35 patients were treated in Oxford or High Wycombe with peritoneovenous shunting. We obtained permission to perform postmortem examinations on 14 of them and report here the relation between clinical and pathological findings in these 14 patients. The findings from laboratory studies on the cells in the malignant ascites and in the blood of 27 of the patients are reported elsewhere (observations in process of being published).

The clinical and necropsy studies described here had the specific objectives of assessing, firstly, whether peritoneovenous shunting results in rapid establishment of widespread haematogenous metastases, with associated symptoms and physical signs, and, secondly, whether observations on the progress of disease in such patients can provide data on factors affecting the spread of metastatic tumours in man.

\section{Patients and methods}

Necropsy was performed on 14 patients who had been treated with peritoneovenous shunting for intractable malignant ascites.

The patients had been seen at intervals to assess the efficacy of drainage of the ascites and to detect clinical evidence, if any, of early or increased dissemination of tumour. As peritoneovenous shunting is performed to alleviate symptoms in patients with incurable abdominal malignancy no systemic chemotherapy or other antineoplastic treatment was administered after insertion of the shunt, and none of the patients received anticoagulants to prevent blockage of the shunt.

Full and detailed necropsies including histological studies were conducted in all cases except one (case 13) in whom a limited necropsy was performed according to the wishes of relatives. All major organs apart from the gut were serially sliced and inspected for the presence of parenchymal metastases. The bowel was opened longitudinally for study of the mucosal and external surfaces. Slices through the vertebral bodies and axial lymph nodes were also examined.

At least six separate blocks of tissue were taken from each large organ for histological examination (the lungs counted as two organs) whereas smaller organs such as the pituitary and appropriate lymph nodes were processed whole. Histological sections were taken from several levels of each block of tissue. Identification of small focal lesions as metastases depended on histological confirmation of the presence of secondary tumour tissue. The haematogenous origin of micrometa- 
stases could be recognised from knowledge of the vascular and lymphatic anatomy of organs.

A metastasis was defined as an expanding focus of tumour cells sharing cytological or histological characteristics with the primary tumour and found either in the interstitial tissue of an organ or completely occluding and distending a blood vessel with associated mural damage.

\section{Results}

\section{CLINICAL OBSERVATIONS}

The table shows clinical details of the patients. Symptoms and signs of partial or total blockage of the shunt were observed in seven. In some of these the signs of reduced drainage were intermittent, but in six patients the shunts eventually needed to be replaced. Further clinical details are provided in an earlier report. ${ }^{1}$

Only one patient (case 7) developed clinical features compatible with metastatic complications, but her breathlessness and signs of right heart failure were subsequently found at necropsy to have been due to massive and propagating pulmonary embolism subtotally occluding the bifurcation of the pulmonary artery. The size and shape of the embolus indicated that it had almost certainly originated from her legs, and no tumour cells or deposits were found in the embolus or the lungs. The remaining patients had symptoms and signs attributable only to increasing tumour mass in the abdomen.

\section{FINDINGS AT POSTMORTEM EXAMINATION}

The table shows findings at necropsy. Six patients were found to have numerous haematogenous metastases while the eight others had none. Although we cannot be certain that metastasis in any patient

Clinical details and findings at necropsy in 14 patients with peritoneovenous shunts

\begin{tabular}{|c|c|c|c|c|c|}
\hline Case No & Sex & $\underset{\text { (years) }}{\text { Age }}$ & $\begin{array}{c}\text { Site of } \\
\text { primary tumour }\end{array}$ & $\begin{array}{l}\text { Survival time } \\
\text { after shunting } \\
\text { (months) }\end{array}$ & $\begin{array}{l}\text { Distribution of } \\
\text { metastases }\end{array}$ \\
\hline $\begin{array}{l}1 \\
2 \\
3 \\
4 \\
5 \\
6 \\
7 \\
7 \\
8\end{array}$ & $\begin{array}{l}\mathrm{F} \\
\mathrm{F} \\
\mathrm{F} \\
\mathrm{M} \\
\mathrm{F} \\
\mathrm{F} \\
\mathrm{F} \\
\mathrm{F}\end{array}$ & $\begin{array}{l}\text { Patient } \\
53 \\
66 \\
68 \\
60 \\
57 \\
48 \\
76 \\
46\end{array}$ & $\begin{array}{l}\text { with no haematoge } \\
\text { Ovary } \\
\text { Ovary } \\
\text { Stomach } \\
\text { Unknown } \\
\text { Ovary and breast } \\
\text { Ovary } \\
\text { Ovary } \\
\text { Ovary }\end{array}$ & $\begin{array}{c}\text { aous metastases } \\
27^{*} \\
2 \\
1 \\
2 ! \\
7 \\
2 \\
4 \\
1\end{array}$ & \\
\hline $\begin{array}{r}9 \\
10 \\
11 \\
12 \\
13 \\
14\end{array}$ & $\begin{array}{l}\mathrm{F} \\
\mathrm{F} \\
\mathrm{M} \\
\mathrm{F} \\
\mathrm{M} \\
\mathrm{F}\end{array}$ & $\begin{array}{l}\text { Patien } \\
82 \\
55 \\
67 \\
59 \\
51 \\
61\end{array}$ & $\begin{array}{l}\text { ts with haematogeno } \\
\text { Ovary } \\
\text { Ovary } \\
\text { Pancreas } \\
\text { Unknown } \\
\text { Bronchus } \\
\text { Colon }\end{array}$ & $\begin{array}{c}\text { us metastases } \\
4 \\
3{ }_{2}^{1} \\
9 \\
5 \\
1 \\
4\end{array}$ & $\begin{array}{l}\text { Several organs } \dagger \\
\text { Lungs } \\
\text { Lungs, liver } \\
\text { Liver, vertebrae } \\
\text { Other lung } \\
\text { Lungs }\end{array}$ \\
\hline
\end{tabular}

* First shunt functioned for five months and second for six months with an interim period of 16 months with an intermittently functioning shunt.

Tiny deposits in lungs, liver, spleen, brain, choroid plexus, intestinal wall, and adrenal gland

$\ddagger$ Large deposits before shunt inserted. Lungs and other organs not affected. $\S$ Pleurovenous shunt.

was the result of peritoneovenous shunting, the uniformity in size of small deposits in the lungs in individual patients with secondary tumour deposits (for example, in cases 10,11, and 14) suggests that they developed synchronously in the short time after the shunt was inserted and were formed by the malignant ascitic cells that it conducted into the circulation. Most importantly, however, none of the patients had similar cohorts of larger $(>1 \mathrm{~cm}$ diameter), potentially debilitating metastases that could be attributed to the shunting of ascitic fluid. All 14 patients died of the consequences of local abdominal tumour growth.

The most remarkable findings, biologically, were in the group of patients with no evidence of haematogenous metastases in any organ. Two of these patients (cases 1 and 5) had survived for several months with continuously functioning shunts and had shown a considerable increase in the abdominal tumour. (Further details of case 1 are provided elsewhere. ${ }^{10}$ ) Even some of the patients in this group who survived for a much shorter time had evidence of further local growth of tumour in the abdomen (in one patient (case 4 ) this led to complete encasement of the peritoneal end of the shunt in tumour) despite the failure of tumour to grow elsewhere.

Detailed histological studies in each patient showed that two of those with no evidence of haematogenous metastases had occasional single tumour cells and tiny cell clumps of three to five cells in the capillaries and in the interstitial tissue of the lungs (case 1) and the liver (case 5). The cells were irrefutably identified as being neoplastic by the presence within them of psammoma bodies, which are laminated calcospherites characteristically produced by ovarian carcinomas and which were also present in the primary tumours of both patients. Without the presence of these natural markers the origin of the cells could not have been recognised and their presence would have gone undetected. We did not regard these disseminated tumour cells as established metastases, although we cannot deny that they might have been dormant progenitors that could have formed metastases at some later time. The remaining six patients with no evidence of haematogenous metastases were totally free of any tumour cells in any sections examined, and we are confident that all eight patients differed radically from those in whom undoubted metastases were easily recognised.

One of the patients with haematogenous metastases (case 12) was exceptional and merits separate consideration. She was already known to have large and numerous hepatic and spinal metastases at the time of insertion of the shunt. These increased in extent in the subsequent months, but, despite the fact that large numbers of viable malignant cells were being infused directly into the jugular vein, no secondary tumour deposits or even isolated tumour cells were found in the lungs or in any organ other than those colonised before the shunt was inserted.

\section{Discussion}

Our findings indicate that, although some tumours might form metastases after dissemination of tumour cells by the shunt, these do not grow fast enough to cause clinically detectable signs and symptoms before the patient dies of the increasing abdominal tumour load. This is of practical importance for those who have to decide whether to use this form of treatment in patients with inoperable malignancy and intractable ascites.

Apart from providing good palliation ${ }^{1}$ the procedure also has the important byproduct of allowing, for the first time, direct analysis of factors affecting the spread of metastatic tumours in man. The most important data scientifically are perhaps provided by the patients in whom no metastases could be detected. We know from laboratory studies that the ascites cells in these patients were viable and neoplastic (observations in process of being published), and clinical observations indicated that large amounts of ascites and hence large numbers of cells entered the blood each day for several weeks. The failure to find metastases in distant sites therefore seems surprising. The findings in the patients in whom haematogenous metastases formed are valuable for comparative purposes and showed that individual differences in behaviour exist even between tumours of homologous organs and histological types. For example, of the seven tumours of the ovary, all of which were serous papillary cystadenocarcinomas, two formed haematogenous metastases whereas the rest did not. These findings in patients with shunts directly infusing tumour cells into the circulation conclusively show that differences in individual metastatic performance are not merely due to differences in the ability of the tumour cells to enter the blood. (The differences in behaviour were also not due to differences in systemic treatment as none was given.) Hence we infer that other tumour specific or host related factors, or both, are responsible, and both possibilities may ethically be studied in patients with peritoneovenous shunts.

The particular value of the opportunities for research provided by this form of treatment is that from the outset at least one of the main conditions for metastasis-that is, dissemination of tumour cells-has been fulfilled and that all tumours start equal in this regard. Furthermore, as the ascites cells, blood, and serum from these patients survive cryopreservation for subsequent use and the presence or absence of metastases is assessed at necropsy research on this sensitive topic requires no further investigation of the patient during life and is therefore not stressful to terminally ill patients. 
In several patients the findings that metastases were forming in some organs but not others, despite infusion of viable tumour cells into the systemic circulation, provides direct evidence supporting the "seed and soil" hypothesis of Paget." This proposes that although haematogenously released tumour cells (seeds) "are carried in all directions they can only live and grow" if they lodge in an organ (soil) that is congenial. The clearest demonstration of this was in the patient (case 12) who was known before insertion of the shunt to have large haematogenous deposits in the liver and bone marrow but in whom there were no metastases or even tumour cells in the lungs or elsewhere at necropsy. With knowledge of such unusual patterns of spread and availability of tumour cells from the same patients it is possible to investigate the host factors responsible for local encouragement or suppression of metastatic growth; these are now being studied in this laboratory. A further point in relation to host related factors is that no cellular immune response was seen in response to micrometastases or isolated tumour cells. Also no features suggesting regression of tumour deposits-for example, dying tumour cells or host lymphoid infiltration-were seen even in those patients who survived for only short periods. It seems unlikely, therefore, that failure to form metastases is due to surveillance by the immune system.

In conclusion, our observations provide otherwise unobtainable information on mechanisms of metastasis in man and confirm that peritoneovenous shunting for malignant ascites does not carry the hazard of promoting clinically important metastasis.

This study was supported by the Cancer Research Campaign of
Great Britain, whose help we gratefully acknowledge. We also thank Mrs P Messer and Mrs B Carter for help in coordinating this study and in preparing the manuscript, and our clinical colleagues for referring cases for treatment.

\section{References}

Souter RG, Tarin D, Kettlewell MGW. Peritoneovenous shunts in the management of malignant ascites. $\mathrm{Br} \mathcal{F}$ Surg 1983;70:478-81.

2 Pollock AV. The treatment of resistant malignant ascites by insertion of a peritoneo-atrial Holter valve. Br f Surg 1975;62:104-7.

${ }^{3}$ Le Veen HH, Wapnick S, Grosberg S, Kinney MJ. Further experience with peritoneo-venous shunt for ascites. Ann Surg 1976;184:574-81.

4 Straus AK, Roseman DL, Shapiro TM. Peritoneovenous shunting in the management of malignant ascites. Arch Surg 1979;114:489-91.

5 Cheung DK, Raaf JH. Selection of patients with malignant ascites for a peritoneovenous shunt. Cancer 1982;50:1204-9.

${ }^{6}$ Reinhold RB, Lokich JJ, Tomashefski J, Costello P. Management of malignant ascites with peritoneovenous shunting. Am f Surg 1983;145: 455-7.

7 Qazi R, Savlov ED. Peritoneovenous shunt for palliation of malignant ascites. Cancer 1982;49:600-2.

${ }^{8}$ Maat B, Oosterlee J, Spaas JAJ, White H, Lammes FB. Dissemination of tumour cells via Le Veen shunt. Lancet 1979;i:988.

9 Smith RR, Sternberg SS, Paglia MA, Golbey RB. Fatal pulmonary tumor embolization following peritoneovenous shunting for malignant ascites. f Surg Oncol 1981;16:27-35.

10 Tarin D, Vass ACR, Kettlewell MGW, Price JE. Absence of metastatic sequelae during long-term treatment of malignant ascites by peritoneovenous shunting: a clinico-pathological report. Invasion and Metastasis $1984 ; 4: 1-12$.

1 Paget S. The distribution of secondary growths in cancer of the breast. Lancet $1889 ; \mathrm{i}: 571-3$.

(Accepted 22 December 1983)

\title{
Smoking and ulcerative colitis
}

\author{
RICHARD F A LOGAN, MARGARET EDMOND, KEVIN W SOMERVILLE, \\ MICHAEL I S LANGMAN
}

\begin{abstract}
In a case-control study of smoking and ulcerative colitis patients with the disease were much less likely to smoke than community controls matched for age and sex. The difference was substantial, with an estimated relative risk of 3.8 for non-smoking on current habits, was even larger (6.2) when habits at onset of the disease were examined, and was mainly accounted for by 42 of 55 patients who had given up smoking a mean of eight years before onset. The association could not be explained by confounding by social class.

These findings suggest that smoking directly or indirectly confers protection against ulcerative colitis.
\end{abstract}

\footnotetext{
University Departments of Therapeutics and Community Health, Queen's Medical Centre, Nottingham NG7 2UH

RICHARD F A LOGAN, MSC, MRCP, Wellcome research fellow in clinical epidemiology (now senior lecturer and honorary consultant physician) MARGARET EDMOND, BSC, research assistant

KEVIN W SOMERVILLE, MB, FRACP, lecturer in therapeutics

MICHAEL J S LANGMAN, MD, FRCP, professor of therapeutics

Correspondence to: Dr Richard F A Logan.
}

\section{Introduction}

The association of non-smoking and ulcerative colitis was first reported by Harries et al in 1982, who found that only $8 \%$ of patients with the disease were smokers compared with $44 \%$ of matched controls attending a fracture clinic. ${ }^{1}$ Jick and Walker, using data collected on hospital admissions, reported similar findings, as have other workers in preliminary reports of two smaller studies. ${ }^{2-4}$ It is not clear whether this unexpected association antedated the onset of disease or whether, as might seem likely, it followed the development or treatment of the disease. Furthermore, no study has included a community based control group, which is desirable when studying habits such as smoking which vary with health and social class.

We have carried out a case-control study inquiring into current and past smoking habits of patients with ulcerative colitis and community controls.

\section{Patients and methods}

The case series included all patients aged $16-80$ from a defined group of 52 general practices who were attending or had previously attended the City Hospital, Nottingham, for ulcerative colitis or proctitis. The hospital records of 124 patients were reviewed to confirm a diagnosis of ulcerative colitis and table I summarises the case details of the 124 patients approached. Ninety five of the patients 